\title{
灌溉区域的数据统计方法及其局限性综述
}

\section{STATISTICAL DATA COLLECTION METHODOLOGIES OF IRRIGATED AREAS AND THEIR LIMITATIONS: A REVIEW}

\author{
ALI AJAZ ${ }^{1 *}$, POOLAD KARIMI ${ }^{2}$, XUELIANG CAI ${ }^{2}$, CHARLOTTE DE FRAITURE $^{2}$ AND MUHAMMAD \\ SALEEM AKHTER ${ }^{3}$
}

\begin{abstract}
${ }^{1}$ Department of Biosystems and Agricultural Engineering, Oklahoma State University, Stillwater, Oklahoma, USA ${ }^{2}$ Land and Water Development for Food Security, Water Science and Engineering, IHE Delft Institute for Water Education, Delft, the Netherlands

${ }^{3}$ Department of Civil and Environmental Engineering, The University of Auckland, New Zealand
\end{abstract}

This article has been published in final form at [https://doi.org/10.1002/ird.2365]. This article may be used for non-commercial purposes in accordance with Wiley Terms and Conditions for Use of Self-Archived Versions

Preprint: $\underline{\text { https://osf.io/cmahg }}$

\section{摘要}

国家层面的灌溉区域统计数据集的不一致可能对制定粮食和水安全政策产生重大影响。遥感可以解决这 个问题; 然而, 对其可靠性的怀疑限制了其主导作用。基于遥感和统计数据集集成的方法似乎是权宜之 计, 但它们更可能被决策者认可。因此, 了解源于国家层面的统计数据集的基础及其局限性于科学家而言 极其重要。。通过综述七个亚洲国家 (中国, 印度, 巴基斯坦, 孟加拉国, 尼泊尔, 印度尼西亚和泰国) 的灌溉区域数据收集方法, 本文指出了造成数据不确定性的因素以及数据收集方法的局限性。为了了解灌 溉区域的空间分布格局与统计记录中不确定性之间的关系, 本文还进行了灌溉密度分布分析。结果发现, 灌溉面积统计数据主要基于水用户协会和农民的信息, 而这些信息是自主报告, 或是调查和普查时访谈收 集到的。出现差异的主要原因有：缺乏经常列举灌溉土地的资源、数据收集方法不一致、次要作物未加说 明、非法和无节制的利用水以及官僚主义和政治限制等。灌溉密度分布分析表明，分散的灌溉区域可能容 易缺乏全面性而频繁的枚举。此外，密集灌溉地区可能存在潜在的未记录灌溉区域，且该区域少数农民进 行了临时或补充灌溉安排。

\section{绪论}

全球有 $70 \%$ 的灌溉区位于亚洲, 关乎 44.2 亿人口的生计, 预计到 2050 年该人口数将达到 52 亿（联合国粮 食及农业组织 (FA0)，2014a; Mukher ji et al., 2009). 如此大量的人口增长将给灌溉基础设施带来沉 重负担，以至于无法满足不断增长的粮食和经济需求，这个问题可以通过对灌溉农业的集约化以及剩余可 能的扩张来实现 (Faurès et al., 2002; Alexandratos and Bruinsma, 2012).预计到 2050 年，亚洲的 用水需求将增加 30-40\%，其中 $80 \%$ 的用水将用于灌溉（Satoh et al. ， 2017). 灌溉农业已经负担了提 高水生产率和产量的重担，还必须与其他利益相关者争夺其水资源份额，即工业和家庭（Asian Development Bank (ADB)，2016). ）。此外，气候变化将是导致灌溉部门在不久的将来面临挑战的一个主 要因素(Krishnamurthy et al., 2015; Kadiresan and Khanal, 2018)。有关灌溉区的可靠信息对于分 析农业用水, 作物水分生产率以及随后制定有助于实现粮食和水安全目标的干预措施至关重要 (Dö11 and Siebert, 1999; Portmann et al., 2010; Karimi et al., 2012). 此外, 由于此类数据的不确定 性，不切实际的政策可能会被制定（Droogers，2002；Kendy et al.，2003). 
灌溉区域数据可分为三大类。首先是源自国家和国家以下各级的统计数据, 并由各国进行分布 (FA0，2018). FAQ（粮农组织）还从成员国那里收到这些统计数据, 这些收集到的数据库在多种不同的平 台上被维护，例如 FAOSTAT, AQUASTAT 和全球灌溉面积图 (GMIA) (Droogers, 2002; Siebert et al. ，2005）第二类是基于遥感（RS）的数据集，其中包括土地覆盖图（例如，美国地质调查局 （USGS），2000; 全球土地覆盖率（GLC），2003； GlobCover -全球土地覆盖图，2010; 欧洲航天局 (ESA)，2015 年），以及专门针对灌溉区域进行制图的遥感研究（e. g. Frolking et al. ， 1999; Alexandridis et al., 2008; Thenkabail et al., 2009a; Siddiqui et al., 2016; Ambika et a1.， 2016)。第三部分结合了基于国家的统计数据和基于遥感 RS 的数据集来绘制灌溉农业地图 (e. g. Pervez and Brown, 2010; Zhu et al., 2014; Salmon et al., 2015; Meier et al., 2018). 据报道, 前两类灌溉面积数据集存在各种不确定性, 这也限制了使用第三种方法获得的灌溉面积统计数据 的准确性。统计数据集包含实际灌溉面积与正式记录的灌溉面积之间的信息差距 (Ajaz et al. , 2016; Ambika et al., 2016), 这可能是由于与数据收集相关的高昂成本, 人力资源的缺乏, 薄弱的机构基础 设施，过时的方法等。（联合国粮食及农业组织（FA0），2016a，2018）。此外，这些数据集在经过多个 官僚和政治层之后由国家和粮农组织传播，这使得统计数据易于被操纵 (Bastiaanssen， 1998； Nickum, 2003; Thenkabail et al., 2009b)。遥感技术, 另一方面, 由于地面实测有限面临精度问 题, 由于输入数据集的空间分辨率造成多边性, 由于云层覆盖和缺乏背景信息而导致的潮湿地区精度较 低，还有独特的稻田制图，遥感(Frolking et al., 1999; Siebert et al., 2005; Xiao et al., 2005; Biggs et al., 2006; Thenkabail et al., 2007; Zhu et al., 2014)。此外, Droogers（2002）和 Jin 等人强调了中由于补充灌溉，像素灌溉的分式估算以及小而分散的灌溉区对灌溉 面积图造成的问题的重要性。（2016）。

在不久的将来，克服统计数据集局限性的进展将相对缓慢（联合国粮食及农业组织（粮农组织），2018 年），而遥感方面的新发展将继续拓宽了对于灌溉农业的地图绘制和监测的视野 (Chen et al. ， 2018; Houborg and McCabe, 2018; Taghvaeian et al., 2018; Pareeth et al., 2019)。这将为遥感技术 开辟新的机会, 以弥补统计数据集的不足。但是, 根据联合国全球工作组（UNGWG）（2017）的研究, 对于 那些已经建立了统计系统的国家来说，从传统统计向基于 RS 的估计的模式转变将并不简单。除了组织对变 革的抵制之外，通常与基于遥感技术的数据集相关的问题（即有效性和不确定性）也减慢了该技术推进的 进程。鉴于这些复杂性，将统计和遥感方法相结合的第三类灌溉面积图看来很有前景，因为它可以协助各 国升级其数据收集系统。此外, 决策者将其视为帮助他们减少国家统计数据差异的工具。因此, 对于研究 人员而言, 重要的是要了解统计数据集的基础架构-制定国家的独特的数据收集方法, 还有其局限性。此 外，了解具有较高潜在差异的区域以及造成这些差异的可能的原因对于研究也很有帮助。

本文的目的是审查七个亚洲国家的不同灌溉区数据收集和报告方法（中国，印度，巴基斯坦，孟加拉国， 尼泊尔, 印度尼西亚和泰国），并分析造成这些国家方法的局限性以及差异的可能原因。另外，本研究使 用 GMIAv5 图进行了灌溉密度分布分析 (Siebert et al.，2005)，从而将数据的不确定性与灌溉区域密 度的空间变化联系起来。

\section{INFORMATION SOURCE}

\section{信息来源}

我们从东亚, 南亚和东南亚中选择了七个亚洲国家 (图 1), 这些国家的灌溉面积范围均有所不同。该选择 具有代表性, 以便审查区域性大国和小国的报告方法。选择国家以及地区时的一些限制因素包括：可用 性, 报告方法的实际应用性, 语言障碍, 以及国家或者地区官员对于获得所需信息是否有延迟甚至不予回 应。 


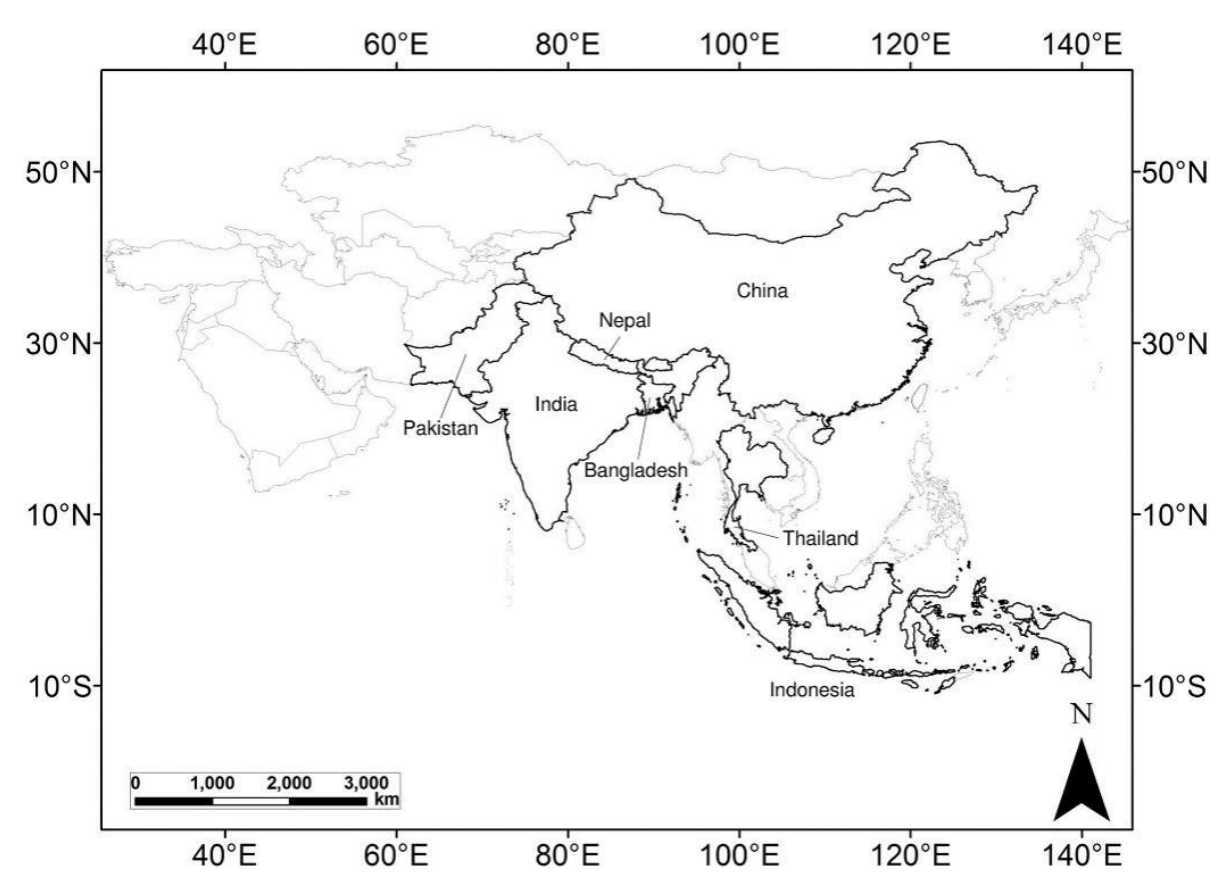

Figure 1. Seven Asian countries selected for the study

图 1 本研究涉及的 7 个亚洲国家

灌溉地区的数据收集方法来自在线资源, 包括选定国家的农业, 灌溉, 水资源和统计部门出版的年度报告 和年鉴。此外, 农业和灌溉普查与调查以及土地使用调查的出版物也被参照。此外, 我们还向选定国家的 在各个部门（例如灌溉, 农业）工作的有关官员发送了调查表。这些调查表主要询问特定部门为记录和验 证其领域内的灌溉区域信息而采取的操作方式。此外, 还寻求有关灌溉水费, 地下水养护区勘察和非正式 的农业灌溉。随后，从官员那里收到的答复被作为个人交流信息被记录在本文中。

\section{IRRIGATION DENSITY DISTRIBUTION}

\section{灌溉密度分布}

一个地区灌溉区域的分布方式可能是造成数据差异的一个因素, 尤其是存在被较低评估问题。例如, 某个 地区或国家中大量分散的灌溉农业可能会妨碍当局的频繁勘察, 并可能导致数据故障。同样, 在密集灌溉 区进行大量灌溉的国家可能存在由于一些原因而未报告给当局的灌溉区域（Meier et al。，2018），例如 不确定的供水补给和制定区域外的灌溉用水。因此, 灌溉密度分布分析提供非常有价值的信息, 可有助于 一个国家深度理解其灌溉农业的空间分布格局。

GMIAv5 被用于这项研究, 它是基于地理信息系统（GIS）的统计灌溉数据的空间分布，主要是从 FA0，世界 银行和灌溉协会的人口普查, 调查和报告中获取的 (Siebert et al., 2013)。根据 Siebert et al. (2005), , 为灌溉配备的单位面积的一小部分被定义为灌溉密度。由于 GMIAv5 根据密度 (单位单元中 AEI 的百分比; 大小为 0.08330 ) 提供了适合灌溉的区域 (AEI), 因此可以对该信息进行分类以发现灌溉密度 的总体空间分布。尽管将灌溉密度分配给不同国家/地区的小区的过程并不完全一致 (Siebert et a1., 2013), 但它可能仍提供了对于一些潜在问题的认识, 这些问题可能是各国要处理以控制其灌溉区域 的统计数据的质量的关键。其他灌溉区域图还可以用来进行灌溉密度分析; 但是, 仅 GMIA 地图被用于此目 的, 因为一些研究通常将其用作统计数据输入的基础地图。ArcMap 10.5 (Esri, Redlands, Calif., USA) 被用于数据处理和地图开发。 
在大多数国家, GMIAv5 的 AEI 像素百分比值范围为从 0 到 100 。将这些数值被分为三类，相应像素对应的 $\mathrm{AEI}$ 被加和。类别为 $1 \%$ 至 $30 \%, 31 \%$ 至 $60 \%$ 和 $61 \%$ 至 100\% , 分别表示为小型, 中型和密集的集中型灌 溉区 (表 1)。此外, 据我们所知, 没有具体设定的规则来确定如何用 AEI 百分比的对密度分布进行分类。 本文对选定国家的灌溉密度分布模式进行了讨论, 并将它们与灌溉面积统计数据差异的潜在原因联系起 来。

Table 1. Categories of irrigated areas summed on the basis of GMIAv5 AEI irrigation density 表 1. 基于 GMIAv5 AEI 灌溉密度百分比的总和的密度分布的类别。

\begin{tabular}{|c|c|}
\hline \multicolumn{1}{|c|}{ Irrigation density category } & $\begin{array}{c}\text { Percentage area equipped for irrigation } \\
\text { 灌溉密度分类 }\end{array}$ \\
\hline Small clustered irrigation 小型集中灌溉区 & $1-30$ \\
\hline Medium clustered irrigation 中型集中溉的区観区 & $31-60$ \\
\hline Densely clustered irrigation 密集型集中灌溉区 & $61-100$ \\
\hline
\end{tabular}

\section{灌溉农业区域报告方法}

\section{中国}

水利部的灌溉面积统计数据（MoWR，2006），被称为有效灌溉面积（EIA），通常基于灌溉项目和乡镇灌溉 站的数据, 这些数据通常由观察灌溉的田地的方法来进行收集 (Nickum, 1995; Yao et al., 2017; personal communication, 2015a)。请注意, EIA 不包括灌溉牧场, 果园和森林 (Zhu et al., 2014). 国家统计局（NBS）的灌溉面积估算（中国国家统计局（NBS），2017），主要源自于基本生产单位向国家 统计局和农业部提交的自我评估报告（Nickum，2003）。2006 年农业普查的灌溉面积统计（中国国家统计 局，2008 年）是基于使用地形图和航空摄影进行的土地利用调查（中国国土资源部，MLR），2007）。

Nickum（2003）指出 MoWR 统计数据可能被过高的评估了, 考虑到对部门的尊敬和预算中的优先等级。而 且, 这些统计数据在传播之前遵循由地区到国家的等级制, 并且似乎容易于被人为调整和修改。此外, 从 渠道的渗水灌溉的土地不包括在灌溉面积统计中。遵循国家统计局自我报告机制的农民可能会低估灌溉面 积, 以寻求减免水费的目的。在不报告灌溉用水量过多的地区的情况下, 灌溉用水的配额也很有可能被超 过(Thevs et al., 2015)。

统计数据中存在的潜在差异也可能与灌溉密度的空间变化有关。灌溉密度分布分析显示, 中国有 25.1 Mha （百万公顷）的 AEI，属于小型集中灌溉区类别，灌溉密度范围为 1\%至 30\%（图 2）。小型集中灌溉区占 灌溉农业的 $40 \%$, 分布在 $274 \mathrm{Mha}$ 的土地上, 主要分布在该国东北部到东南部。从行政的角度来看, 在这 些地区保持合理的灌溉土地数据质量可能是非常具有挑战性的, 特别是在依靠传统统计方法的时候 
（Biggeri，2002）。此外，中型集中灌溉区灌溉面积为 23.7 Mha，集密型灌溉面积为 13.1 Mha, 在华东 地区集中度较高。

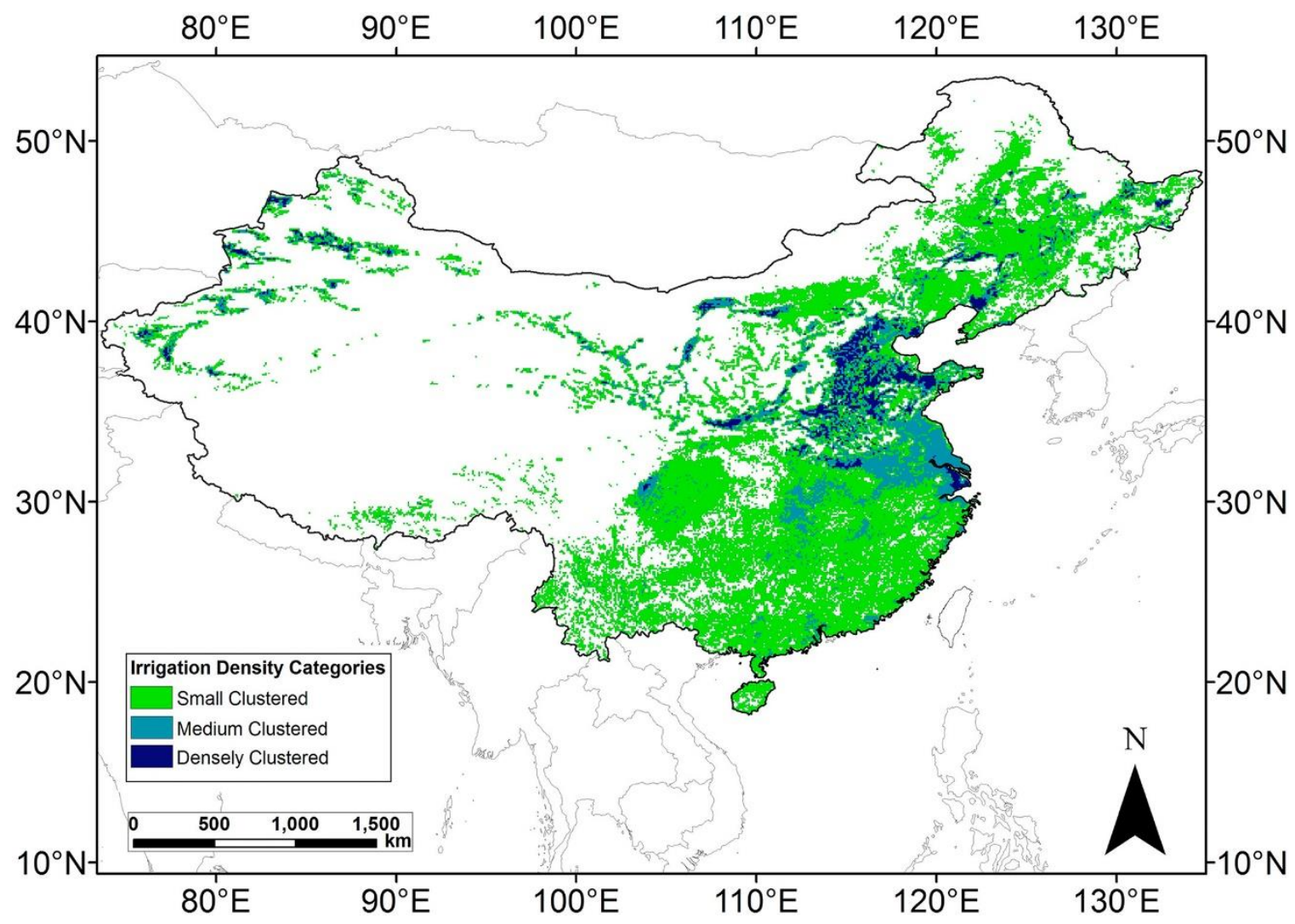

Figure 2. Irrigation density distribution in China (Data source: FAO - GMIAv5 - AEI; Siebert et al., 2005)

图 2 中国境内灌溉密度分布（数据来源：FAO - GMIAv5 - AEl; Siebert et al., 2005)

\section{结论}

为了发现灌溉区域的统计数据集和报告方法的局限性和差异性的潜在原因，本文对包括中国、印度、 巴基斯坦、孟加拉国、尼泊尔、印度尼西以及泰国在内的七个亚洲国家进行了综述。此外，为了了解数据 差异与国家层面灌溉农业的空间分布格局之间的联系，本文分析了灌溉密度分布。结果发现，灌溉区域的 统计数据集主要基于从农民处接收或收集的信息，例如水用户协会的自我报告和针对村庄中单个农户的采 访。此外, 自我报告的信息不一定经过了当局的验证。样本枚举被广泛用于收集灌溉面积信息以及其他农 业统计数据。此外，专家估算通常大量用于偏远地区的灌溉地区统计数据中。

灌溉区域统计数据集中存在差异的重大潜在原因如下:

・缺乏定期更新记录的资源;

-由于补充灌溉或临时灌溉安排，在密集灌溉地区存在未报告的面积;

•在大部分分散的灌溉区域中，采用低效的枚举方法;

・对主要作物给予特别重视, 然而忽略了其他灌溉作物;

・非法使用运河灌溉水; 
・不受管制地开采地下水;

・官僚主义和政治限制导致低估和高估问题。

由于同时使用统计数据集和遥感数据的灌溉面积统计是权宜之计, 因此科学家应了解来自这些国家的 信息基础以及不确定性的可能原因。为了确保更好地管理农业用水, 并制定切实可行的水和粮食安全政 策, 不可避免地需要获得有关灌溉土地的准确信息。因此, 各国需通过允许修正政策、法规、基建模式以 及采用技术进步等方法, 来解决数据差异的问题。

\section{Cite as:}

Ajaz, A., Karimi, P., Cai, X., De Fraiture, C., \& Akhter, M. S. (2019). Statistical Data Collection Methodologies of Irrigated Areas and Their Limitations: A

Review. Irrigation and Drainage, 68(4), 702-713.

\section{参考文献}

Alexandratos N, Bruinsma J. 2012. World agriculture towards 2030/2050 the 2012 revision, ESA Working Paper No. 12-03. Retrieved from http://www.fao.org/docrep/016/ap106e/ap106e.pdf.

Alexandridis TK, Zalidis GC, Silleos NG. 2008. Mapping irrigated area in Mediterranean basins using low cost satellite Earth Observation. Computers and Electronics in Agriculture, 64(2), 93-103. doi: 10.1016/j.compag.2008.04.001.

Ambika AK, Wardlow B, Mishra V. 2016. Remotely sensed high resolution irrigated area mapping in India for 2000 to 2015, Sci. Data, 3, 160118, doi:10.1038/sdata.2016.118.

Asian Development Bank (ADB). 2016. Irrigation efficiency key to meeting Asia's growing food demands, Retrieved from https://www.adb.org/news/features/irrigation-efficiency-key-meetingasia-s-growing-food-demands.

Bangladesh Agricultural Development Corporation (BADC). 2010. Minor irrigation survey report. Irrigation by methods 1979-80 to 2009-10, Bangladesh, Retrieved from http://brri.portal.gov.bd/sites/default/files/files/brri.portal.gov.bd/page/b6531346_66a5_45e7_9cb0 _d00c7c7009dc/Irrigation\%20by\%20Methods.pdf.

Bangladesh Bureau of Statistics (BBS). 2008. Census of agriculture, structure of agricultural holdings \& livestock population. Retrieved from http://www.fao.org/fileadmin/templates/ess/ess_test_folder/World_Census_Agriculture/Country_in fo_2010/Reports/Reports_3/BGD_ENG_REP_2008.pdf.

Bangladesh Bureau of Statistics (BBS). 2012. Statistical yearbook of Bangladesh. 32nd edition. Retrieved from 
http://203.112.218.65:8008/WebTestApplication/userfiles/Image/SubjectMatterDataIndex/YB2012.pdf.

Bastiaanssen WGM. 1998. Remote sensing in water resources management: The state of the art. International Water Management Institute. Colombo, Sri Lanka. Retrieved from http://publications.iwmi.org/pdf/H022865.pdf.

Biggeri L. 2002. China agricultural census design and data collection: issues and lessons. Retrieved from

http://www.stats.gov.cn/english/specialtopics/IntConferenceOnAgCensus/200205/t20020520_2992 8.html.

Biggs TW, Thenkabail PS, Gumma MK, Scott CA, Parthasaradhi GR, Turral HN. 2006. Irrigated area mapping in heterogeneous landscapes with MODIS time series, ground truth and census data, Krishna Basin, India. International Journal of Remote Sensing, 27:19, 4245-4266. doi: $10.1080 / 01431160600851801$.

Blake DJH. 2012. Irrigationalism: The politics and ideology of irrigation development in the Nam Songkhram Basin, Northeast Thailand. Doctoral thesis, University of East Anglia, city, United Kingdom. Retrieved from https://ueaeprints.uea.ac.uk/47934/1/2012BlakeDJHPhD.pdf.

Badan Pusat Statistik (BPS). 2013. Land Area by Utilization 2013. Retrieved from https://www.bps.go.id/publication/2014/09/12/a38655384c9199260bed9590/luas-lahan-menurutpenggunaan-2013.html.

Central Bureau of Statistics (CBS). 2012. Number, area, number of holdings reporting and area irrigated by source of irrigation by total area of holding, Nepal Living Standards Survey 2010-2011. NLSS Third, Methodology. Retrieved from http://cbs.gov.np/nada/index.php/catalog/37/studydescription.

Central Bureau of Statistics (CBS). 2013. National Sample Census of Agriculture Nepal 2011/12 National, National Report, Government of Nepal, National Planning Commission Secretariat, Central Bureau of Statistics, Kathmandu, Nepal. Retrieved from http://cbs.gov.np/image/data/Agriculture/National\%20Level/NATIONAL\%20REPORT\%202011_ 12.pdf.

Chen Y, Lu D, Luo L, Pokhrel Y, Deb K, Huang J, Ran Y. 2018. Detecting irrigation extent, frequency, and timing in a heterogeneous arid agricultural region using MODIS time series, Landsat imagery, and ancillary data. Remote Sensing of Environment, 204, 197-211. doi:10.1016/j.rse.2017.10.030. 
Directorate of Economy and Statistics (DES). 2001. Net area irrigated from different sources and gross irrigated area - all India, Retrieved from https://data.gov.in/catalog/net-area-under-irrigationsources.

Directorate of Economy and Statistics (DES). 2012. Agricultural statistics at a glance. Retrieved from http://eands.dacnet.nic.in/Publication12-12-2012/Agriculture_at_a_Glance\%202012/Pages137.pdf.

Department of Irrigation (DOI). 2007. Development of database for irrigation development in Nepal. Planning, Design, and Monitoring \& Evaluation Division. Retrieved from http://doi.gov.np/wpcontent/uploads/2015/10/IrrigationDatabaseFinalReport.pdf.

Döll P, Siebert S. 1999. A digital global map of irrigated areas. Report A9901, Centre for Environmental Systems, Research, University of Kassel, Kurt Wolters Strasse 3, 34109 Kassel, Germany. Retrieved from https://www.uni-frankfurt.de/45217807/doell_siebert_kwws1.pdf.

Droogers P. 2002. Global irrigated area mapping: Overview and recommendations. Working Paper 36. Colombo, Sri Lanka: International Water Management Institute. Retrieved from http://www.iwmi.cgiar.org/Publications/Working_Papers/working/WOR36.pdf.

Droogers P, Immerzeel WW, Lorite IJ. 2010. Estimating actual irrigation application by remotely sensed evapotranspiration observations. Agricultural Water Management, 97(9), 1351-1359. doi:10.1016/j.agwat.2010.03.017.

European Space Agency (ESA). 2015 ESA CCI land cover, http://maps. elie.ucl.ac.be/CCI/viewer/index.php.

Food and Agriculture Organization of the United Nations (FAO). 2014a. Area equipped for irrigation, Retrieved from http://www.fao.org/nr/water/aquastat/infographics/Irrigation_eng.pdf.

Food and Agriculture Organization of the United Nations (FAO). 1996. Census enumeration, Chapter 14, FAO Statistical Development Series No. 6, Conducting Agricultural Censuses and Surveys, Rome, Italy. Retrieved from http://www.fao.org/economic/the-statistics-division-ess/world-census-ofagriculture/conducting-of-agricultural-censuses-and-surveys/en/.

Food and Agriculture Organization of the United Nations (FAO). 2007a. Metadata for national agricultural statistics in Bangladesh. http://www.fao.org/fileadmin/templates/ess/documents/meetings_and_workshops/manilla06/final_ country_reports/bangladesh/bangladesh_cr_full_document.doc. 
Food and Agriculture Organization of the United Nations (FAO). 2008. Country reports, Pakistan, Emerging Issues Asia and Pacific Commission on Agricultural Statistics, p.31. Retrieved from http://www.fao.org/3/a-bt538e.pdf.

Food and Agriculture Organization of the United Nations (FAO). 2010. Country reports. China. Asia and Pacific Commission on Agricultural Statistics (APCAS) 23rd Session, Retrieved from http://www.fao.org/economic/ess/ess-events/ess-apcas/ess-apcas23/la/.

Food and Agriculture Organization of the United Nations (FAO). 2010b. Country reports. Thailand. Asia and Pacific Commission on Agricultural Statistics APCAS. 23rd Session. Retrieved from http://www.fao.org/economic/ess/ess-events/ess-apcas/ess-apcas23/la/.

Food and Agriculture Organization of the United Nations (FAO). 2014a. Asia and the Pacific must increase food production to meet future demand. Retrieved from http://www.fao.org/news/story/en/item/216042/icode/.

Food and Agriculture Organization of the United Nations (FAO). 2014b. Evolution of irrigation development, irrigation and drainage, Bangladesh. Retrieved from http://www.fao.org/nr/water/aquastat/countries_regions/BGD/.

Food and Agriculture Organization of the United Nations (FAO). 2014c. Report on in-depth capacity assessment of Bangladesh to produce agricultural and rural statistics, Implementation of Global Strategy to Improve Agricultural and Rural Statistics, Retrieved from www.fao.org/3/a-az471e.pdf.

Food and Agriculture Organization of the United Nations (FAO). 2016a. Data and statistics, Retrieved from http://www.fao.org/3/a-i5180e.pdf.

Food and Agriculture Organization of the United Nations (FAO). 2016b. AQUASTAT Main Database, Retrieved from http://www.fao.org/nr/water/aquastat/main/index.stm.

Food and Agriculture Organization of the United Nations (FAO) (2018. Global strategy to improve agricultural and rural statistics in ASIA-PACIFIC. Retrieved from http://www.fao.org/documents/card/en/c/I9299EN.

Faurès J-M, Hoogeveen J, Bruinsma J. 2002. The FAO irrigated area forecast for 2030, Retrieved from http://www.fao.org/tempref/agl/AGLW/docs/fauresetalagadir.pdf.

Frolking S, Xiao X, Zhuang Y, Salas W, Li C. 1999), Agricultural land-use in China: a comparison of area estimates from ground-based census and satellite-borne remote sensing. Global Ecology and Biogeography, 8: 407-416. doi:10.1046/j.1365-2699.1999.00157.x. 
Global Land Cover (GLC). 2003. Global land cover 2000 database. European Commission, Joint Research Centre, http://forobs.jrc.ec.europa.eu/products/glc2000/glc2000.php.

GlobCover - Global Land Cover Map. 2010. GlobCover project, European Space Agency, http://due.esrin.esa.int/page_globcover.php.

Government of Pakistan (GoP), International Union for Conservation of Nature (IUCN). 2003. Northern areas strategy for sustainable development. IUCN Pakistan, Karachi. Pakistan. xxiii+85 pp. Received from https://portals.iucn.org/library/sites/library/files/documents/2003-095.pdf.

Houborg R, McCabe MF. 2018. A Cubesat enabled Spatio-Temporal Enhancement Method (CESTEM) utilizing Planet, Landsat and MODIS data. Remote Sensing of Environment, 209, 211-226. doi: 10.1016/j.rse.2018.02.067.

Japan International Cooperation Agency (JICA). 2007. The agricultural statistics and economic analysis development project, summary of evaluation results. Thailand. Retrieved from http://open_jicareport.jica.go.jp/pdf/11825981_04.pdf.

Jin N, Tao B, Ren W, Feng M, Sun R, He L, Zhuang W, Yu Q. 2016. Mapping Irrigated and Rainfed Wheat Areas Using Multi-Temporal Satellite Data. Remote Sens. 8, 207. doi: 10.3390/rs8030207.

Kadiresan K, Khanal PR. 2018. Rethinking Irrigation for Global Food Security. Irrigation and Drainage, 67: 8-11. doi: 10.1002/ird.2219.

Kayastha KB. 2012. Agriculture Census of Nepal 2011/12, 24th session of the Asia and Pacific Statistical Commission on agricultural statistics, Da Lat, Viet Nam, 8-12 Oct. 2012, Retrieved from http://www.fao.org/fileadmin/templates/ess/ess_test_folder/Workshops_Events/APCAS_24/PPT/A PCAS-12-12-_Nepal_Ag_Census.pdf.

Kendy E, Molden DJ, Steenhuis TS, Liu CM, Wang J. 2003. Policies drain the North China Plain: agricultural policy and groundwater depletion in Luancheng County, 1949-2000 Research Report 71. International Water Management Institute. Colombo, Sri Lanka. Retrieved from http://ageconsearch.umn.edu/bitstream/44560/2/Report71.pdf.

Krishnamurthy PK, Lewis K, Kent C, Aggarwal P. 2015. Climate impacts on food security and livelihoods in Asia, A review of existing knowledge. Retrieved from https://reliefweb.int/sites/reliefweb.int/files/resources/wfp281745.pdf. 
Kumar MD, Reddy VR, Narayanamoorthy A, Sivamohan MVK. 2013. Analysis of India's Minor Irrigation Statistics, Economic and Political Weekly, 48(45-46). Retrieved from https://www.researchgate.net/publication/291845169.

Margono H. 2013. Agricultural statistical system country case: Indonesia. Retrieved from www.unsiap.or.jp/e-learning/el_material/Agri/rap1/ag_01_01_Theme_I.pdf.

Meier J, Zabel F, Mauser W. 2018. A global approach to estimate irrigated areas - a comparison between different data and statistics. Hydrology and Earth System Sciences 22:1119-1133. doi: 10.5194/hess-22-1119-2018.

Ministry of Agriculture (MoA). 2005. Minor irrigation survey report 2004-05 (Bangladesh) paperback. city, Bangladesh.

Ministry of Agriculture (MoA). 2010. Aplikasi database lahan (Indonesia). Retrieved from http://prasarana.pertanian.go.id/lahanmy/home.

Ministry of Agriculture (MoA). 2015. Centre for Agriculture Data and Information Systems, Agricultural statistics system in Indonesia. Retrieved from http://www.fao.org/fileadmin/templates/rap/files/meetings/2015/1506157_Agricultural_Statistics_System__Indonesia.pdf.

Ministry of Land and Resources, China (MLR). 2007. Surveying and mapping management and services, Communique on Land and Resources of China 2006. Retrieved from http://old.mlr.gov.cn/mlrenglish/magazine/2006/200711/t20071108_90714.html.

Ministry of Statistics and Program Implementation (MSPI). 2018a. Irrigation statistics. Retrieved from http://www.mospi.gov.in/48-irrigation-statistics.

Ministry of Statistics and Program Implementation (MSPI). 2018b. Crop area statistics. Retrieved from http://www.mospi.gov.in/42-crop-area-statistics.

Ministry of Statistics and Program Implementation (MSPI). 2018c. Agricultural statistics. Retrieved from http://mospi.nic.in/23-agricultural-statistics.

Ministry of Water Resources (MoWR), River Development and Ganga Rejuvenation India. 2014. Fourth census of minor irrigation schemes report, Minor Irrigation (Statistics) Wing. Retrieved from http://mowr.gov.in/sites/default/files/Census_of_Minor_Irrigation_Schemes_Report_201314_0.pdf. 
Ministry of Water Resources (MoWR). 2006. Main achievements in water sector, irrigation, Statistics Bulletin on China Water Activities, p. 34, Retrieved from http://www.mwr.gov.cn/english/publs/.

Ministry of Water Resources (MoWR). 2017. Report of 5th census of minor irrigation schemes. Retrieved form

http://www.indiaenvironmentportal.org.in/files/file/Report\%20of\%205th\%20Census\%20of\%20Mi nor\%20Irrigation\%20Schemes.pdf.

Molle F. 2001. Water pricing in Thailand: theory and practice. Kasetsart University, DORAS Centre, Research Report No. 7. city, Thailand. Retrieved from http://horizon.documentation.ird.fr/exldoc/pleins_textes/pleins_textes_7/sous_copyright/010032459.pdf.

Mukherji A, Facon T, Burke J, de Fraiture C, Faurès J-M, Füleki B, Giordano M, Molden D, Shah T. 2009. Revitalizing Asia's irrigation: to sustainably meet tomorrow's food needs. International Water Management Institute. Colombo, Sri Lanka; Food and Agriculture Organization of the United Nations. Rome, Italy. Retrieved from http://www.iwmi.cgiar.org/Publications/Other/PDF/Revitalizing\%20Asia\%27s\%20Irrigation.pdf.

Mustafa D. 2001. Colonial law, contemporary water issues in Pakistan, Political Geography, 20, 817837. doi: 10.1016/S0962-6298(01)00025-7.

National Bureau of Statistics (NBS) China. 2017. Irrigated area of cultivated land and consumption of chemical fertilizers 12-5, http://www.stats.gov.cn/tjsj/ndsj/2017/indexeh.htm.

National Bureau of Statistics (NBS) China. 2008. Communiqué on major data of the Second National Agricultural Census of China (No. 6). Retrieved from http://www.stats.gov.cn/english/NewsEvents/200803/t20080303_25999.html.

National Informatics Centre (NIC)-a. nd. Evolution of land record system and collection of agriculture statistics, Agriculture Census in India. Retrieved from http://agcensus.nic.in/ACI1.html.

National Informatics Centre (NIC)-b. nd. Methodology \& phases of data collection, Agriculture Census. Retrieved from http://agcensus.nic.in/ACI5.html.

Nickum JE. 1995. Dam lies and other statistics, taking the measure of irrigation in China, 1931-91. EastWest Centre Occasional Papers. Environmental Series No.18. Retrieved from https://scholarspace.manoa.hawaii.edu/bitstream/10125/21621/1/ENVOp018DamLiesAndOtherSta tistics1995\%5Bpdfa\%5D.PDF. 
Nickum JE. 2003. Irrigated area figures as bureaucratic construction of knowledge: the case of China, International Journal of Water Resources Development, 19:2, 249-262.doi: 10.1080/0790062032000089347.

Office of Agriculture Economics (OAE). 2015. Irrigated area - Thailand. Retrieved from http://www.afsisnc.org/statistics (irrigation statistics missing from new version http://www.aptfsis.org/index.php/statistics).

Ozdogan M, Yang Y, Allez G, Cervantes C. 2010. Remote Sensing of Irrigated Agriculture: Opportunities and Challenges, Remote Sens. 2(9). 2274-2304. doi:10.3390/rs2092274PBS (2010).

Pakistan Bureau of Statistics (PBS). 2010. Agricultural census 2010 Pakistan report. All Pakistan Tables. Retrieved from http://www.pbs.gov.pk/content/agricultural-census-2010-pakistan-report.

Pakistan Bureau of Statistics (PBS). 2011. Methodology of crop estimates. Retrieved from http://www.pbs.gov.pk/content/methodology-crop-estimate.

Pakistan Bureau of Statistics (PBS). 2018. Area irrigated by different sources, http://www.pbs.gov.pk/content/table-4-area-irrigated-different-sources.

Palash M. Bauer S. 2017. Diversification of farmland use in Bangladesh: land allocation impacts on farm profitability. Open Agriculture, 2(1), pp. 175-188. Retrieved 22 Jun. 2018, from doi:10.1515/opag2017-0018.

Personal Communication. 2015a, b, c, d. Questionnaire based information retrieval via email, a- Local irrigation official from Dongying China; b- Executive Engineer (BWDB) from Bangladesh; cDepartment of Irrigation's Senior Divisional Engineer from Nepal; d- Ministry of Public works' irrigation department official from Indonesia.

Personal Communication. 2017. Questionnaire based information retrieval via email, Deputy District Officer (On farm water management) from Pakistan.

Personal Communication. 2018. Questionnaire based information retrieval via email, RID representative from Thailand.

Pervez MS, Brown JF. 2010. Mapping Irrigated Lands at 250-m Scale by Merging MODIS Data and National Agricultural Statistics. Remote Sensing, 2(10), 2388-2412. doi:10.3390/rs2102388. 
Portmann FT, Siebert S, Döll P. 2010. MIRCA2000_-global monthly irrigated and rainfed crop areas around the year 2000: a new high-resolution data set for agricultural and hydrological modeling. Glob Biogeochem Cycles 24:24. doi:10.1029/2008GB003435.

Qureshi AS, Ahmed Z, Krupnik TJ. 2014. Groundwater management in Bangladesh: an analysis of problems and opportunities. Cereal Systems Initiative for South Asia Mechanization and Irrigation (CSISA-MI) Project, Research Report No. 2., CIMMYT. Dhaka, Bangladesh. Retrieved form http://csisa.org/wp-content/uploads/sites/2/2014/01/Groundwater-management-in-Bangladesh-Ananalysis-of-problems-and-opportunities.pdf.

Rattanatangtrakul U. 2017. Participatory Irrigation Management (PIM) in Thailand, Water Management Development Group, Office of Hydrology and Water Management. Retrieved from www.rid.go.th/thaicid/_5_article/2549/07PIM.pdf.

Royal Irrigation Department (RID). 2008. Number of drainage area, agricultural area, irrigated area, potential area and irrigated area / potential area by region: fiscal year 2007 (T-22.2) http://service.nso.go.th/nso/nsopublish/download/yearBook51/Format Excel/Chapter22.xls.

Salmon JM, Friedl MA, Frolking S, Wisser D, Douglas E. 2015. Global Rain-fed, Irrigated, and Paddy Croplands: A New High Resolution Map Derived from Remote Sensing, Crop Inventories and Climate Data, submitted to International Journal of Applied Earth Observation and Geoinformation. doi: 10.1016/j.jag.2015.01.014, Data available at http://ftpearth.bu.edu/public/friedl/GRIPCmap/.

Satoh Y, Kahil T, Byers E, Burek P, Fischer G, Tramberend S, Greve P, Flörke M, Eisner S, Hanasaki N, Magnuszewski P, Nava LF, Cosgrove W, Langan S, Wada Y. 2017. Multi-model and multiscenario assessments of Asian water futures: The Water Futures and Solutions (WFaS) initiative. Earth's Future, 5: 823-852. doi:10.1002/2016EF000503.

Shah T. 2011. Past, present and the future of canal irrigation in India. IWMI. Colombo, Sri Lanka. Retrieved from http://www.idfc.com/pdf/report/2011/Chp-6-Past-Present-and-the-Future-of-CanalIrrigation.pdf.

Siddiqui S, Cai X. Chandrasekharan K. Irrigated area map Asia and Africa (International Water Management Institute, 2016. http://waterdata.iwmi.org/applications/irri_area/.

Siebert S, Döll P, Hoogeveen J, Faures J-M, Frenken K, Feick S. 2005. Development and validation of the global map of irrigation areas. Hydrology and Earth System Sciences. doi:10.5194/hess-9-5352005. 
Siebert S, Henrich V, Frenken K, Burke J. 2013. Update of the digital global map of irrigation areas to Version 5. Rheinische Friedrich-Wilhelms-University, Bonn, Germany, Food and Agriculture Organization of the United Nations, Rome, Italy. doi: 10.13140/2.1.2660.6728.

Siebert S, Kummu M, Porkka M, Döll P, Ramankutty N, Scanlon BR. 2015. A global data set of the extent of irrigated land from 1900 to 2005. Hydrology and Earth System Sciences. 3-19, pp 15211545. doi: 10.5194/hess-19-1521-2015.

Sinclair AJ, Kumnerdpet W, Moyer JM. 2013. Learning sustainable water practices through participatory irrigation management in Thailand. Nat Resour Forum, 37: 55-66. doi:10.1111/1477-8947.12012.

Srivastava S. Kumar R. 2007. Irrigation development and groundwater extraction in Uttar Pradesh state: emerging issues of distribution and sustainability. Retrieved from https://www.researchgate.net/publication/265979791.

Taghvaeian S, Neale CMU, Osterberg JC, Sritharan SI, Watts DR. 2018. Remote Sensing and GIS Techniques for Assessing Irrigation Performance: Case Study in Southern California. Journal of Irrigation and Drainage Engineering, 144(6), 5018002. doi:10.1061/(ASCE)IR.19434774.0001306.

Tahir Z. Habib Z. 2000. Land and water productivity: trends across Punjab canal commands. International Water Management Institute (IWMI) working Paper 14. Colombo, Sri Lanka. doi: 10.3910/2009.155.

Thenkabail PS, Biradar CM, Noojipady P, Cai X, Dheeravath V, Li YJ, Velpuri M, Gumma MK, Pandey S. 2007. Sub-pixel area calculation methods for estimating irrigated areas, Sensors, 7:2519-2538. doi: $10.3390 / \mathrm{s} 7112519$.

Thenkabail PS, Biradar CM, Noojipady P, Dheeravath V, Li YJ, Velpuri M, Reddy GPO, Cai XL, Gumma M, Turral H, Vithanage J, Schull M, Dutta R. 2009a. Global irrigated area map (GIAM), derived from remote sensing, for the end of the last millennium, International Journal of Remote Sensing, 30:14, 3679-3733, doi: 10.1080/01431160802698919.

Thenkabail PS, Dheeravath V, Biradar CM, Gangalakunta ORP, Noojipady P, Gurappa C, Velpuri M, Gumma M, Li Y. 2009b. Irrigated Area Maps and Statistics of India Using Remote Sensing and National Statistics. Remote Sens. 1, 50-67. doi: 10.3390/rs1020050. 
Thevs N, Peng H, Rozi A, Zerbe S, Abdusalih N. 2015. Water allocation and water consumption of irrigated agriculture and natural vegetation in the Aksu-Tarim river basin, Xinjiang, China, J. Arid Environ., 112, 87-97, doi 10.1016/j.jaridenv.2014.05.028.

Ul Haq A. 1998. Case study of the Punjab Irrigation Department: consultancy report. International Irrigation Management Institute (IIMI). Pakistan National Program. x, 157p. (IWMI Pakistan Report C-012 / IIMI Pakistan Report C-012). Lahore, Pakistan. doi: 10.3910/2009.550.

United Nations Global Working Group (UNGWG). 2017. Earth observations for official statistics, Satellite Imagery and Geospatial Data Task Team report, Retrieved from https://unstats.un.org/bigdata/taskteams/satellite/UNGWG_Satellite_Task_Team_Report_WhiteCo ver.pdf.

US Geological Survey (USGS). 2000. Global land cover characteristics data base version 2.0, https://lta.cr.usgs.gov/glcc/globdoc2_0.

Xiao X, Boles S, Liu J, Zhuang D, Frolking S, Li C, Moore III B. 2005. Mapping paddy rice agriculture in southern China using multi-temporal MODIS images. Remote Sens. Environ. 95 (4), 480-492. doi: /10.1016/j.rse.2004.12.009.

Yao L, Zhao M, Xu T. 2017. China's Water-Saving Irrigation Management System: Policy, Implementation, and Challenge. Sustainability, 9, 2339. doi: 10.3390/su9122339.

Zhu X, Zhu W, Zhang J, Pan Y. 2014. Mapping Irrigated Areas in China from Remote Sensing and Statistical Data. IEEE Journal of Selected Topics in Applied Earth Observations and Remote Sensing, Vol. 7, No. 11. doi: 10.1109/JSTARS.2013.2296899. 